\title{
Enhancing Seed Production of Three Brassica vegetables by Honey Bee Pollination in North-western Himalayas of India
}

\author{
S.N. Sushil", J. Stanley, N.K. Hedau, J.C. Bhatt \\ Vivekananda Institute of Hill Agriculture, Indian Council of Agriculture, Almora - 263 601, India \\ *Corresponding Author: snsushil3@gmail.com
}

Copyright $@ 2013$ Horizon Research Publishing All rights reserved.

\begin{abstract}
The impact of planned honeybee pollination on the seed production of three Brassica vegetables, Brassica oleacea var. italica, B. rapa pekinensis and B. oleracea var. gongylodes and the pollination behaviour of Apis mellifera was studied under Indian Himalayan conditions. Among the three crops tested, more number of bees were found visiting broccoli crop under net house condition (6.05 bees/plant) followed by kohlrabi (5.35 bees/plants) and Chinese cabbage (5.05 bees/plant). Bees spent more time in Chinese cabbage flower $(6.92 \mathrm{sec})$ while it was $6.50 \mathrm{sec}$ in broccoli and $5.54 \mathrm{sec}$ in kohlrabi. Bees in the open conditions were found to spend less time in a flower as compared to the net house conditions. Honeybees played an important role in enhancing the seed production of all the crops under study. Planned honeybee pollination was found to inflict maximum impact on the seed production of broccoli with an increase in seed yield of 29.2 per cent. The net profit was also more in case of broccoli, which was calculated to be $1324.60 \$$ per ha in honeybee pollinated broccoli crop when compared to the natural pollinated crop.
\end{abstract}

Keywords Honey Bee, Apis Mellifera, North West Himalayas, Broccoli, Kohlrabi, Chinese Cabbage

\section{Introduction}

The focus of agriculture in Himalayan region is slowly shifting from traditional cereal crops to high value vegetable crop cultivation. Owing to the prolonged cold weather, cruciferous vegetable cultivation is said to be successful in this region. The diversified Brassica family contains over 3500 species in 300 genera of which most of them are important to the diet and economic welfare of people throughout the world (Wills, 1973). Brassica vegetables like broccoli, Brassica oleracea var. italica Plenck, Chinese cabbage, B. rapa pekinensis (Lour.) Hanelt., Kohlrabi, B. oleracea var. gongylodes L. are grown in the north western Indian Himalayas during cropping season and also in off seasons under protected/polyhouse conditions. This transformation from subsistence agriculture to commercial agriculture possesses new challenges for improving the productivity and quality of vegetables (Pratap, 1999). Low seed yield due to inadequate pollination is often faced as a major problem of Brassica seed production. Inadequate pollination is caused by several factors and the most important of which includes the lack of adequate number and diversity of pollinators. Thus, there is a need to ensure pollination by conserving the pollinators and attracting them towards the crop land. This can be achieved only through planned honeybee pollination, owing to the fact that honeybees are the only pollinators which we can managed. Seed production of Brassica vegetables is done by the farmers, research Institutions and many non- governmental agencies. Pollination by insects is inevitable for Brassica, since they are generally incompatible (Sihag, 2001) and the pollen is heavier and sticky, which is unable to be easily wind borne. Even though, the bees are reported as marvelously coevolved pollen transferring devices for Brassicas (http://www.fastplants.org), the pollination potential and economic importance of the effect of honeybees on these vegetables is still need to be established. The productivity of the crops is in decreasing trend due to the lack of desired level of pollinators, while pollination services of honey bees has not been realized and under estimated by the farmers and policy makers (Pratap and Pratap, 2000). A number of factors such as species of bees, foraging preference, bee biology etc appear to influence crop pollination (Neupane et al., 2006). Thus, the present study aims in establishing the pollination potential of honeybees on the important Brassica crops.

\section{Materials and Methods}

\subsection{Growing of Crops}


All the three brassica vegetables under study viz., broccoli, Chinese cabbage and Khol rabi were grown with recommended seed rate, spacing and other proper agronomic practices.

\subsection{Rearing of Honey Bees}

The study was conducted at the experimental farm of Vivekananda Institute of Hill Agriculture, Hawalbagh, Almora at $79^{\circ} 39^{\prime}$ E Latitude, $29^{\circ} 35^{\prime} \mathrm{N}$ Longitude and 1250 $\mathrm{m}$ above $\mathrm{msl}$ in North Western Himalayas of India during 2006-2008. Honey bees (A. mellifera F.) were reared in Langstroth boxes of size $50 \times 40 \times 30 \mathrm{~cm}$ at the experimental farm. Healthy honey bee colonies were maintained with regular monitoring and necessary treatments.

\subsection{Pollination Behaviour}

Broccoli was grown for seed production in net house of $100 \mathrm{~m} 2$ area in the experimental farm. During anthesis, one frame honeybee colony of $A$. mellifera containing approximately 1000 bees in a bee box was kept inside the net house to aid in pollination (Figure 1). Foraging activities like, time spent by a bee per flower and number of flowers visited by a bee per minute were observed by using a stop watch. The observations were made for six days when the plant was at full bloom. Pollination behaviour was noticed at 12 Noon when there is bright sun shine and more bee activity.

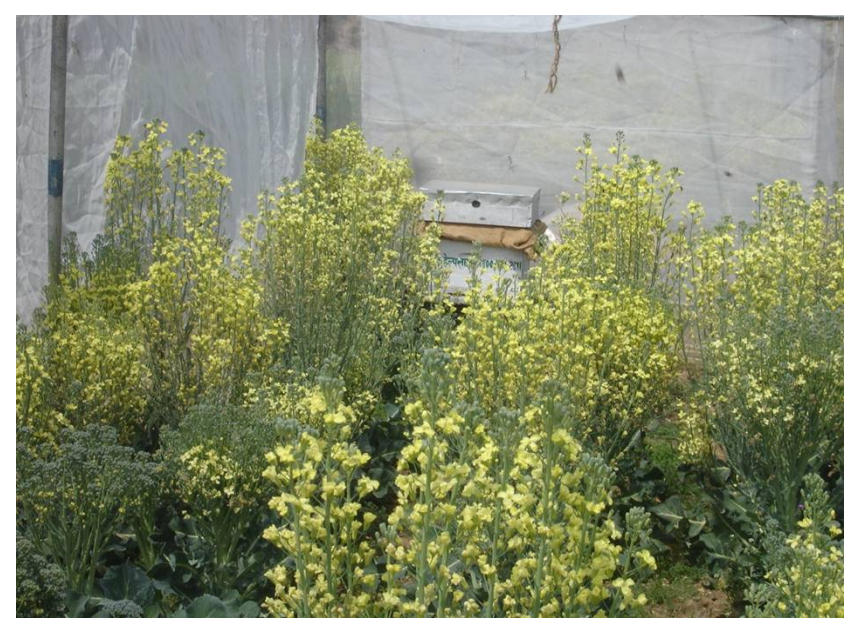

Figure 1. Honey bee box kept in net house for pollination

\subsection{Impact on Seed Production}

At the time of harvest, twenty randomly selected plants were tagged and number of pods per plant, number of seeds per pod and 1000 seed weight (5 replications) were recorded. The total seed yield in the net house area of 100 $\mathrm{m} 2$ was also recorded and yield per ha was calculated. Another $50 \mathrm{~m} 2$ uncaged area was kept for natural pollination for comparison. Twenty plants were selected randomly from the naturally pollinated crop and tagged for number of pods, number of seed and 1000 seed weight recording. Total seed yield in this uncaged area $(50 \mathrm{~m} 2)$ was also recorded to calculate the seed yield in naturally pollinated crop. Similar experiment on planned honeybee pollination was conducted in Chinese cabbage and kohlrabi crops grown for seed production in the same farm. The experiments were repeated in the second year also in the same manner to confirm the results.

\section{Results}

\subsection{Pollination Behaviour}

Results of the pollination behaviour of A. mellifera to different brassica vegetables have been presented in table 1 . The average number of foraging bees/plant was highest in broccoli (6.05) followed by kohlrabi (5.35) and Chinese cabbage (5.05) in net house condition, while it was 1.65 in broccoli, 1.30 in Chinese cabbage and 1.35 in kohlrabi under open condition. The average time spent by bees per flower was found to be higher in case of Chinese cabbage (6.92) followed by broccoli (6.45) and kohlrabi (5.54) in planned pollination compared to naturally pollinated Chinese cabbage (6.82), broccoli (6.20) and kohlrabi (5.39). The average number of flowers visited per minute showed a deviation from the above trend. In this case, the figures revealed higher values for open condition with kohlrabi occupying the first position with 9.65 flowers visited per minute followed by broccoli (8.40) and Chinese cabbage (6.55) than in net house condition recorded in a similar order [kohlrabi (9.40); broccoli (8.15) and Chinese cabbage (6.45)].

\subsection{Impact on Seed Production}

Planned honeybee pollination has increased the overall performance of the plants in terms of seed production and seed vigour. During 2006-07, broccoli plants under planned honeybee pollination have produced 52.80 pods per panicle as against 46.20 pods in natural pollinated crop, with an increase in pod setting to a tune of $12.50 \%$. There was an increase of $12.25 \%$ in seeds per pod in planned honeybee pollinated crops and $9.09 \%$ increase in thousand seed weight resulting in $28.14 \%$ increase in seed yield in broccoli crop. Chinese cabbage plants produced 42.70 pods per panicle in planned honey bee plots as against 36.40 pods in natural pollination. An increase of $10.88 \%$ seeds per pod was observed in honeybee introduced crops resulted in $11.88 \%$ increase in seed yield. In kohlrabi, there was 42.30 pods per panicle in planned honeybee treatments where as it was 35.70 pods in the other plot. The thousand seed weight was found to be 4.15 and $3.97 \mathrm{~g}$ in the planned honeybee and natural pollinated crops, respectively. The increase in seed yield was found to be $20.00 \%$ during $2006-07$ in kohlrabi crop (Table 2). 
Table 1. Pollination behaviour of A. mellifera to different Brassica vegetables

\begin{tabular}{|c|c|c|c|c|c|c|}
\hline \multirow{2}{*}{ Parameters } & \multicolumn{2}{|c|}{ Broccoli } & \multicolumn{2}{|c|}{ Chinese cabbage } & \multicolumn{2}{|c|}{ Kohlrabi } \\
\hline & Caged & Open & Caged & Open & Caged & Open \\
\hline Average no. of bees/ plant & $\begin{array}{c}6.05 \\
(1.15)\end{array}$ & $\begin{array}{c}1.65 \\
(0.88)\end{array}$ & $\begin{array}{c}5.05 \\
(1.05)\end{array}$ & $\begin{array}{c}1.30 \\
(0.86)\end{array}$ & $\begin{array}{c}5.35 \\
(1.09)\end{array}$ & $\begin{array}{c}1.25 \\
(0.85) \\
\end{array}$ \\
\hline Average time spent/ flower & $\begin{array}{c}6.45 \\
(0.80)\end{array}$ & $\begin{array}{c}6.50 \\
(0.81)\end{array}$ & $\begin{array}{c}6.92 \\
(0.72)\end{array}$ & $\begin{array}{c}6.82 \\
(0.81)\end{array}$ & $\begin{array}{c}5.54 \\
(0.98)\end{array}$ & $\begin{array}{c}5.39 \\
(0.78) \\
\end{array}$ \\
\hline Average No. of flowers visited/ $\min$. & $\begin{array}{c}8.15 \\
(1.60)\end{array}$ & $\begin{array}{c}8.40 \\
(1.64)\end{array}$ & $\begin{array}{c}6.45 \\
(1.67)\end{array}$ & $\begin{array}{c}6.55 \\
(1.47)\end{array}$ & $\begin{array}{c}9.40 \\
(1.31)\end{array}$ & $\begin{array}{c}9.65 \\
(1.35) \\
\end{array}$ \\
\hline
\end{tabular}

(Mean of six days observation)

Figures in the parentheses are standard deviation (SD) values

Table 2. Effect of planned honey bee pollination in the seed production of Brassica vegetables

\begin{tabular}{|c|c|c|c|c|c|c|c|}
\hline \multirow{2}{*}{ Crops } & \multicolumn{4}{|c|}{ 2006-07 } & \multicolumn{3}{|c|}{ 2007-08 } \\
\hline & Criteria & Natural & Planned & Per cent increase & Natural & Planned & Per cent increase \\
\hline \multirow{4}{*}{$\begin{array}{l}\text { Broccoli var. Pusa } \\
\text { samridhi }\end{array}$} & Pods per panicle & $\begin{array}{c}46.20 \\
(10.13) \\
\end{array}$ & $\begin{array}{l}52.80 \\
(6.01) \\
\end{array}$ & 12.50 & $\begin{array}{l}48.20 \\
(8.59) \\
\end{array}$ & $\begin{array}{l}55.10 \\
(4.78) \\
\end{array}$ & 12.52 \\
\hline & Seeds per pod & $\begin{array}{l}13.60 \\
(4.11) \\
\end{array}$ & $\begin{array}{l}15.50 \\
(2.11) \\
\end{array}$ & 12.25 & $\begin{array}{l}13.20 \\
(4.32) \\
\end{array}$ & $\begin{array}{l}16.70 \\
(1.98) \\
\end{array}$ & 20.96 \\
\hline & 1000 seed weight & $\begin{array}{c}3.00 \\
(0.07) \\
\end{array}$ & $\begin{array}{r}3.30 \\
(0.07) \\
\end{array}$ & 9.09 & $\begin{array}{c}3.04 \\
(0.06) \\
\end{array}$ & $\begin{array}{r}3.36 \\
(0.04) \\
\end{array}$ & 9.52 \\
\hline & $\begin{array}{l}\text { Seed yield } \\
(\mathrm{Kg} / \mathrm{ha})\end{array}$ & 416.80 & 580.00 & 28.14 & 439.30 & 620.50 & 29.20 \\
\hline \multirow{4}{*}{$\begin{array}{c}\text { Chinese cabbage var. } \\
\text { open type }\end{array}$} & Pods per panicle & $\begin{array}{l}36.40 \\
(7.92) \\
\end{array}$ & $\begin{array}{l}42.70 \\
(4.22) \\
\end{array}$ & 14.75 & $\begin{array}{l}40.20 \\
(3.91) \\
\end{array}$ & $\begin{array}{l}45.80 \\
(3.43) \\
\end{array}$ & 12.23 \\
\hline & Seeds per pod & $\begin{array}{l}17.20 \\
(4.94) \\
\end{array}$ & $\begin{array}{l}19.30 \\
(2.79) \\
\end{array}$ & 10.88 & $\begin{array}{l}16.70 \\
(3.33) \\
\end{array}$ & $\begin{array}{l}19.10 \\
(3.16) \\
\end{array}$ & 12.57 \\
\hline & 1000 seed weight & $\begin{array}{c}1.08 \\
(0.04) \\
\end{array}$ & $\begin{array}{c}1.14 \\
(0.03) \\
\end{array}$ & 5.26 & $\begin{array}{c}1.00 \\
(0.11) \\
\end{array}$ & $\begin{array}{c}1.11 \\
(0.07) \\
\end{array}$ & 9.91 \\
\hline & $\begin{array}{l}\text { Seed yield } \\
(\mathrm{Kg} / \mathrm{ha})\end{array}$ & 178.00 & 202.00 & 11.88 & 187.00 & 212.85 & 12.14 \\
\hline \multirow{4}{*}{$\begin{array}{l}\text { Knol-khol var. white } \\
\text { vinnea }\end{array}$} & Pods per panicle & $\begin{array}{l}35.70 \\
(7.38) \\
\end{array}$ & $\begin{array}{l}42.30 \\
(4.34) \\
\end{array}$ & 15.60 & $\begin{array}{l}39.10 \\
(3.23) \\
\end{array}$ & $\begin{array}{l}45.60 \\
(4.38) \\
\end{array}$ & 14.25 \\
\hline & Seeds per pod & $\begin{array}{l}16.00 \\
(3.98) \\
\end{array}$ & $\begin{array}{l}17.94 \\
(2.82) \\
\end{array}$ & 10.81 & $\begin{array}{l}15.25 \\
(3.75) \\
\end{array}$ & $\begin{array}{l}17.15 \\
(2.37) \\
\end{array}$ & 11.08 \\
\hline & 1000 seed weight & $\begin{array}{c}3.97 \\
(0.10) \\
\end{array}$ & $\begin{array}{c}4.15 \\
(0.09) \\
\end{array}$ & 4.34 & $\begin{array}{c}3.88 \\
(0.15) \\
\end{array}$ & $\begin{array}{c}4.19 \\
(0.07) \\
\end{array}$ & 7.40 \\
\hline & $\begin{array}{c}\text { Seed yield } \\
(\mathrm{Kg} / \mathrm{ha})\end{array}$ & 120.00 & 150.00 & 20.00 & 143.00 & 187.00 & 23.53 \\
\hline
\end{tabular}

Figures in the parentheses are standard deviation (SD) values 
Table 3. Economics of planned honey bee pollination in Brassica vegetables

\begin{tabular}{|c|c|c|c|c|c|c|}
\hline \multirow{2}{*}{ Crops } & \multicolumn{2}{|c|}{ Yield (Kg/ha) } & \multirow{2}{*}{$\begin{array}{l}\text { Additional yield } \\
\qquad \mathrm{Kg} / \mathrm{ha})\end{array}$} & \multirow{2}{*}{$\begin{array}{l}\text { Monetary benefits } \\
\text { (in US \$) }\end{array}$} & \multirow{2}{*}{$\begin{array}{l}\text { Cost for keeping } \\
\text { bee boxes per ha.* } \\
\text { (in US \$) }\end{array}$} & \multirow{2}{*}{$\begin{array}{c}\text { Net benefit per } \\
\text { ha. } \\
\text { (in US \$) }\end{array}$} \\
\hline & $\begin{array}{c}\text { Natural } \\
\text { pollinated }\end{array}$ & $\begin{array}{l}\text { Planned honey bee } \\
\text { pollinated }\end{array}$ & & & & \\
\hline Broccoli & 439.30 & 620.50 & 181.20 & 1449.60 & 125.00 & 1324.60 \\
\hline Chinese cabbage & 187.00 & 212.85 & 25.85 & 206.80 & 125.00 & 81.80 \\
\hline Kohlrabi & 143.00 & 187.00 & 44.00 & 352.00 & 125.00 & 227.00 \\
\hline
\end{tabular}

* by taking $25 \$$ per bee box.

\# by taking $8 \$$ per $\mathrm{kg}$ seed.

In 2007-08 also, planned honeybee pollination has increased the number of pods per panicle, seed per pod and thousand seed weight when compared to natural pollinated crops. The seed yield of broccoli was $620.50 \mathrm{~kg} / \mathrm{ha}$ in planned honeybee pollinated crop, while the naturally pollinated crops yielded $439.30 \mathrm{~kg} / \mathrm{ha}$. There was an increase in the pods per panicle to a tune of $12.23 \%$ in planned honeybee pollinated Chinese cabbage over natural pollinated crop. The seed yield was also high up to 212.85 $\mathrm{kg} / \mathrm{ha}$ in planned honeybee pollinated crop whereas it was $187.00 \mathrm{~kg} / \mathrm{ha}$ in the crop left for natural pollination. The increase in pods per panicle and seeds per pod has increased to a tune of 14.25 and $11.08 \%$, respectively in honeybee introduced crop over natural pollinated crop of kohlrabi. An increase of $7.40 \%$ in thousand seed weight of honeybee introduced crop was also observed, resulting in an increase of $23.53 \%$ in seed yield of honey bee pollinated crop over natural pollinated crop.

\subsection{Economics of Honeybee Pollination}

An additional seed yield of $181.20,25.85$ and $44.00 \mathrm{Kg} /$ ha was obtained incase of from broccoli, Chinese cabbage and kohlrabi crops respectively in planned honeybee pollinated crops. Among the three crops tested, the additional yield was very high in case of broccoli, with the monetary benefits of $\$ 1449.60$ per ha followed by kohlrabi \$ 352 and Chinese cabbage \$206.8 When the cost of bee keeping is included, a net profit of $\$ 1324.60$ can be obtained in broccoli seed production followed by kohlrabi (\$227.0) and Chinese cabbage (\$81.80).

\section{Discussion}

Pollination behaviour of A. mellifera in broccoli, Chinese cabbage and knol-khol was studied to know the crop of preference and to compare the bee behaviour inside the net house and open conditions. Since it was reported that a number of factors influence the presence of bee in a plant and significant difference was observed in different intervals of a day and stage of the crop (Aly and Hassan, 1999), the present study was done for six days when the crop was at the full bloom and at 12 Noon when the bee activity was high. The number of bees per plant was found to be very less in open condition. Since the bees were introduced inside the net house, the number inside the net house was found to be higher. Thus, the number of pods per panicle and seeds per pod and the seed yield was higher in the net house when compared to open field conditions. A. mellifera was found to spend more time in Chinese cabbage than the other two crops under study. Bees in open conditions were found to spend less time in a flower when compared to the net house condition. This may be due to the availability of large number of flowers for less number of bees to forage upon in the open conditions. Similar trend was observed in case $A$. mellifera which was reported to spend less time in broccoli flowers kept in open than in caged conditions (Devkota et al., 2003; Devkota and Tapa, 2005). Honeybees showed less flower visiting frequency under caged conditions as compared to the open condition, as indicated by bees visiting more flowers in open than in net house.

Planned honeybee pollination was found to have a positive influence on the pod setting, seed sitting and the seed yield of all the three crops under study. It is rightly pointed out by Abrol (2007) that insect pollinators not only enhance the yield of the crop but also contribute uniform and early pod setting. Variation in pod setting and filling of seeds was found in the naturally pollinated crop when compared to planned honeybee pollinated crops which is evident from higher values of standard deviation (Table 2). It was reported that the increase in seeds per siliqua was $24.15 \%$ in $A$. mellifera introduced broccoli over natural pollinated crop in Chitwan, Nepal. The thousand seed weight was also reported to be $3.64 \mathrm{~g}$ and $3.21 \mathrm{~g}$ in honeybee pollinated and natural crop, respectively (Devkota et al., 2003).

In the present study, the seed yield was found to increase to a tune of $29.20,12.14$ and $23.53 \%$ in broccoli, Chinese cabbage and kohlrabi crops, respectively during 2007-08, which is in conformity with the findings of Devkota et al. (2003), who reported an increase in seed yield of $21.87 \%$ in A. mellifera pollinated broccoli over naturally pollinated crop. Crane (1991) has reported an increase in seed yield in honeybee pollinated Chinese cabbage trial which is in conformity with the present finding. Duran et al. (2010) stated an increase in yield of $50.34 \%$ in honey bee introduced field of Brassica napus with that of plots without bees.

Among the three corps tested, the seed yield was found to have increased to a greater extent in honeybee introduced broccoli i.e., $439.30 \mathrm{Kg} /$ ha (natural crop) to $620.50 \mathrm{Kg} / \mathrm{ha}$ (bee introduced crop). This indicates the importance of 
honeybee in broccoli seed production than the other crops. Among the three crops tested, Brassica rapa is self incompatible and cross pollination is done by external means such as honeybees (Williams et al., 1987), however wind pollination is also there up to a distance of $2.5 \mathrm{~km}$ (Timmons et al., 1995). Thus, Chinese cabbage (B. rapa) can be pollinated by wind also. Hence, in the present study, yield increase was less in Chinese cabbage compared to other crops. Though honeybees are important for the pollination of all the three brassica vegetable crops, they are inevitable for broccoli seed production. Therefore, utilization of honeybees is imperative for enhancing the seed production of brassica vegetables.

\section{Acknowledgements}

The work was funded by the Horticultural Technology Mission (Mini Mission-I), Uttarakhand, India.

\section{REFERENCES}

[1] D. P. Abrol. Honey bees and rape seed: A pollinator plant interaction. Advances in Botanical Research, Vol 45, 337-367, 2007.

[2] A. M. Aly, A. R. Hassan, Foraging preference of honeybees for pollen of some maize varieties in middle Egypt. Proceedings of the 23rd International Beekeeping Congress, Vancuvor, Canada. 270p, 1999.

[3] E. Crane. Apis species of tropical Asia as pollinators and some rearing methods for them. Acta Horticulturae, Vol. 288, 29-48, 1991.

[4] F. R. Devkota, G. Upreti, R. B. Thapa, S. M. Shakya, U. Pratap. Impact of Honeybee Pollination on Productivity and Quality of Broccoli Seed under Chitwan Condition. Journal of Institute of Agriculture and Animal Sciences, Vol. 24,
85-89, 2003.

[5] F. R. Devkota, R. B. Tapa. Forage preference of Apis mellifera L. to broccoli under caged and open conditions in Chitwan. Journal of Institute of Agriculture and Animal Sciences, 26, 167-168, 2005

[6] X. A. Duran, R. B. Ulloa, J. A. Carrillo, J. L. Contreras and M. T. Bastidas. Evaluation of yield component traits of honeybeepollinated (Apis mellifera L.) rapeseed canola (Brassica napus L.). Chilean Journal of Agricultural Research, 70, 309-314, 2010.

[7] A. M. Timmons, E. T. O'Brien, Y. M. Charters, S. J. Dubbles, M. J. Wilkinson. Assessing the risks of wind pollination from fields of genetically modified Brassica napus ssp. oleifera. Euphytica, Vol. 85, 417-423, 1995

[8] K. R. Neupane, D. D. Dhakal, R. B. Thapa, D. M. Gautam. Foraging preference of giant honeybee, Apis dorsata F., to selected Horticultural crops. Journal of Institute of Agriculture and Animal Sciences, Vol. 27, 87-92, 2006

[9] T. Pratap. Sustainable land management in marginal mountain areas of the Himalayan region. Mountain Research and Development, Vol. 19, 251-260, 1999.

[10] U. Pratap, T. Pratap. Farming strategies to manage declining crop productivity of apples due to pollination failures. In: Proc of 7th IBRA Conference and 5th AAS Conference, Chaing Mai, Thailand. 118p, 2000.

[11] R. C. Sihag. Why should bee-keeping be utilized as an input in agriculture? Current Science, Vol. 81, 1514-16, 2001.

[12] I. H. Williams, A. P. Martin, R. P. White. The effect of insect pollination on plant development and seed production in winter oilseed rape (Brassica napus L.). Journal Agricultural Science Cambridge, Vol. 109, 135-139, 1987

[13] J. C. Wills. A dictionary of the Flowering Plants and Ferns. Eighth edition. Cambridge University Press, Cambridge. $1245 \mathrm{p}, 1973$

[14] http://www.fastplants.org/pdf/activities/bees brassicas.pdf. Bees and Brassicas: A partnership in survival. University of Wisconsin- Madison. College of Agricultural and Lifesciences. Retrived from internet on 29.03.2009. 